Persp. Teol. 37 (2005) 199-224

\title{
COLEGIALIDADE EPISCOPAL NO VATICANO II O CONCÍLIO CONVIDA-NOS A RESGATAR UM DADO FUNDAMENTAL DA TRADIÇÃO ECLESIAL
}

\author{
Paulo César Barros SJ
}

RESUMO: A colegialidade episcopal constitui um dos mais importantes temas eclesiológicos do Concílio Vaticano II. Com o intuito de fazer contrapeso ao ensinamento do Concílio Vaticano I sobre o ministério petrino, os Padres conciliares, no Vaticano II, acentuaram o valor no episcopado e explicitaram a forma colegial como aquela própria do governo eclesiástico. É de se lamentar, contudo, que os caminhos abertos pelo Vaticano II em termos de colegialidade episcopal não tenham sido ainda trilhados, o que traria frutos para a vida eclesial como um todo, e para o progresso do ecumenismo em particular. Já passados quarenta anos da conclusão do Vaticano II, as Conferências Episcopais não gozam da autonomia que mereceriam enquanto lugar natural de se praticar a colegialidade, e o Sínodo dos Bispos, por seu turno, não se tem mostrado como instrumento apto a promover uma maior comunhão entre os prelados e, conseqüentemente, entre as Igrejas locais.

PALAVRAS-CHAVE: Vaticano II, colegialidade, episcopado, papado, comunhão.

ABSTRACT: Episcopal collegiality constitutes one of the most important ecclesiological themes of Vatican II. In order to counterbalance Vatican I teachings on the Petrine ministry, during the Vatican II the conciliar Fathers emphasized the 
value of the episcopacy and the collegiality as the way of ecclesiastical government. It is regrettable, however, that the ways opened by the Vatican II in terms of Episcopal collegiality have not been trod yet. This would have bore fruits to the ecclesial life as a whole, and to the progress of ecumenism in particular. It has been forty years since the Vatican II conclusion and the Episcopal Conferences do not enjoy the autonomy they would deserve as natural place of practicing the collegiality. Similarly, the Synod of Bishops has not been working as an apt instrument to promote a greater communion among the prelates and, consequently, among the local Churches.

KEY-WORDS: Vatican II, collegiality, episcopacy, papacy, communion.

\section{Contextualização histórica}

$\mathrm{O}$

Concílio Vaticano I (8/dez./1869 - 20/out./1870), sobejamente conhe cido pela proclamação dos dogmas do primado de jurisdição e da infalibilidade do magistério solene do Papa, passou à história como um "concílio inacabado". De fato, em razão de circunstâncias que lhes foram impostas pelo momento histórico-político na Europa de então, não puderam os Padres conciliares elaborar uma satisfatória teologia do episcopado que viesse a servir de contrapeso à doutrina do múnus pontifício. Em razão da guerra franco-prussiana, e mais precisamente, da invasão de Roma pelas tropas italianas no dia 20 de setembro de 1870, o Papa Pio IX, no dia 20 de outubro do mesmo ano, suspendeu as atividades do Concílio sine die. Ora, os trabalhos do Vaticano I jamais foram retomados.

Todavia, menos de um século depois, o Concílio Vaticano II (11/out./1962 - 8/dez./1965), em sua constituição dogmática sobre a Igreja, propôs em especial a doutrina do episcopado ${ }^{1}$, de modo a ensejar uma sadia e profícua articulação entre o ministério do Romano Pontífice e aquele dos Bispos. Há estudiosos que reconhecem ter sido providencial a brusca interrupção do Vaticano I, pois naquela época a reflexão teológica entre os católico-romanos não estava em condições de fazer chegar a uma satisfatória formulação dogmática sobre o episcopado². Com efeito, estudos nos cam-

${ }^{1}$ Como reza o título do capítulo terceiro da Lumen Gentium (LG): "Sobre a constituição hierárquica da Igreja e, em especial, sobre o episcopado" ("De constitutione hierarchica Ecclesiae et in specie de Episcopatu”). O itálico é nosso.

${ }^{2}$ Ver a propósito: R. AUBERT, Vatican I, Paris: L'Orante, 1964, p. 247; G. MARTINA, La Chiesa nell'età dell'assolutismo, del liberalismo, del totalitarismo, vol. 3: L'età del liberalismo, Brescia: Morcelliana, 41980, p. 222; P. EYT, "La collégialité", in Le Deuxième Concile du Vatican (1959-1965), Rome: École Française de Rome, 1989, pp. 539-548, aqui p. 542. 
pos da Sagrada Escritura, da Patrística, da Liturgia, da História da Igreja e do Ecumenismo, nas décadas imediatamente anteriores ao Vaticano II, vieram a enriquecer a reflexão teológica como um todo - e da eclesiologia em particular - em âmbito estritamente católico-romano. Foi quando surgiram, nas fileiras da Igreja católica, figuras de elevada estatura teológica, como um Rahner ou um Congar, por exemplo. De modo sumário, pode-se dizer que neste tempo imediatamente anterior ao Vaticano II, para recordar a bela e conhecida expressão de Romano Guardini, deu-se um "despertar da Igreja nos corações dos fiéis".

Apresentando em especial a doutrina do episcopado quando trata da constituição hierárquica da Igreja, a Constituição Dogmática Lumen Gentium obviamente não relega ao esquecimento a doutrina do múnus pontifício, exposta pela Constituição Dogmática Pastor Aeternus (PA) do Concílio Vaticano I. O Vaticano II, na verdade, recebe este conteúdo dogmático do Concílio que lhe antecedeu e, dando um passo adiante, elabora a doutrina sobre o episcopado, esforçando-se por colocar em harmonia estes dois ensinamentos. É evidente, sem dúvida nenhuma, a intenção que teve o Concílio Vaticano II de completar o Concílio anterior no que tange a uma equilibrada visão do governo hierárquico da Igreja ${ }^{3}$.

O grande e inspirado projeto de aggiornamento levado a efeito pelo Papa João XXIII, quando da convocação do Vaticano II, tinha como intenção fundamental apresentar a imagem de uma Igreja capaz de dialogar com o homem contemporâneo. Entende-se, desta forma, a direção que tomou o Concílio em vista da correção de uma concepção "monárquica" da Igreja, cuja construção inicia-se já no pontificado de Gregório VII (1020-1085; eleito papa em 1073). Com fundamento nas Escrituras e na Tradição eclesial (Padres, Liturgia, História da Igreja etc.), o Concílio buscou resgatar a imagem da Igreja-comunhão, feita de ministérios os mais diversos, entre os quais se encontra aquele do governo hierárquico, exercido pelos Bispos espalhados por todo o orbe e em comunhão com o Bispo de Roma.

Entre as motivações que o levaram a convocar o Vaticano II, Ângelo Roncalli manifestava aquela de uma abertura ecumênica por parte da Igreja católica romana. Por certo, jamais os católico-romanos poderíamos dialogar com os

\footnotetext{
${ }^{3}$ Em LG 18 b, lê-se: "Esta doutrina sobre a instituição, perpetuidade, poder e natureza do sacro Primado do Romano Pontífice e sobre seu infalível Magistério, o Sagrado Sínodo novamente a propõe para ser crida firmemente por todos os fiéis. $E$ continuando na mesma iniciativa, resolveu declarar e professar diante de todos a doutrina sobre os Bispos, sucessores dos Apóstolos, que junto com o Sucessor de Pedro, Vigário de Cristo e Cabeça visível de toda a Igreja, regem a casa do Deus vivo". O itálico é nosso.
} 
"irmãos separados" sem que nos dispuséssemos a rever a nossa forma de governo hierárquico. Se, como viria a dizer mais tarde o Papa Paulo VI, o papado é o maior obstáculo ao diálogo com os membros de outras confissões cristãs, a sensibilidade ecumênica do Papa Roncalli não deixaria de levá-lo ao esforço de recuperar uma forma de governo hierárquico que se caracterizasse menos pelo poder e mais pelo serviço, menos pela pompa e mais pelo despojamento, menos pela lei e mais pelo amor.

Ora, no amplo contexto da revisão que faz o Vaticano II da forma de governo hierárquico exercido na Igreja católica romana, é proposto com inequívoca transparência o conceito de colegialidade episcopal, ainda que a palavra "colegialidade" como tal não apareça nos textos conciliares. O governo eclesiástico, do qual são investidos os Bispos em comunhão com o Romano Pontífice, segundo a Tradição eclesial, não pode se dar senão ao modo colegial, vale dizer, senão como expressão de comunhão e solicitude por toda a Igreja de Cristo.

\section{O ensinamento do Vaticano II}

\section{Doutrina do episcopado}

Como se disse acima, o Concílio Vaticano II recebe o ensinamento do Concílio Vaticano I sobre o primado de jurisdição (cf. Denzinger-Schönmetzer [DS] 3053-3064) e da infalibilidade do magistério solene (cf. DS 3065-3075) do Papa; todavia, põe-no em relação com o ministério dos Bispos no que toca, respectivamente, ao munus regendi e ao munus docendi dos Pastores.

\section{(a) Quanto ao munus regendi}

Quanto ao munus regendi do Papa e dos Bispos, eis o que afirma o Concílio: "o Romano Pontífice, em virtude do seu múnus de Vigário de Cristo e Pastor de toda a Igreja, possui na Igreja poder pleno, supremo e universal. Mas a Ordem dos Bispos, que sucede ao Colégio Apostólico no magistério e no regime pastoral e na qual em verdade o Corpo Apostólico continuamente perdura, junto com seu Chefe o Romano Pontífice e nunca sem ele, é também detentora do poder supremo e pleno sobre a Igreja inteira" (LG 22b) ${ }^{4}$. Com efeito, Cristo "está presente no meio dos

\footnotetext{
${ }^{4}$ Cite-se também CD 2a-b: "Nesta Igreja de Cristo, o Romano Pontífice, como sucessor de Pedro, a quem Cristo confiou suas ovelhas e seus cordeiros para apascentar, tem, por instituição divina, poder supremo, pleno, imediato e universal na cura das almas. [...] Mas também os Bispos, postos pelo Espírito Santo, sucedem aos Apóstolos como pastores das almas. Juntamente com o Sumo Pontífice e sob sua autoridade receberam a missão
} 
crentes na pessoa dos Bispos, assistidos pelos presbíteros. Assentado à destra de Deus Pai, [Cristo] não está ausente da congregação dos seus pontífices, mas sobretudo pelo exímio serviço deles prega a todas as gentes a palavra de Deus e continuamente administra os sacramentos da fé a todos os crentes" (LG 21a) . Mais: "assim como permanece o múnus que o Senhor concedeu singularmente a Pedro, [...] da mesma forma permanece o múnus dos Apóstolos de apascentar a Igreja" (LG 20c) desta forma, que o Concílio se apresse em afirmar que os Bispos "não devem ser considerados como vigários do Romano Pontífice. Seu poder, portanto, não é diminuído pelo poder universal e supremo, antes, pelo contrário, é assegurado, consolidado e defendido" (LG 27b) 7 . Recorde-se, porém, que a missão canônica dos Bispos deve ser consentida pelo Romano Pontífice (cf. LG 24b).

\section{(b) Quanto ao munus docendi}

Ainda com o intuito de completar o Concílio Vaticano I mediante a explicitação de uma conveniente teologia do episcopado, o Vaticano II situa o dogma da infalibilidade do magistério solene do Papa em relação com o magistério dos Bispos. Estes - uma vez dadas as condições necessárias - "enunciam infalivelmente a doutrina de Cristo" (LG 25b) ${ }^{8}$. A infalibilidade, a rigor, é graça do Espírito de Cristo dada ao Povo de Deus, formado de fiéis e pastores em comunhão (cf. LG 12a, 25c). É assim que o Povo de Deus, na sua totalidade, é constituído como "lugar teológico" no qual a Verdade de Cristo é buscada e encontrada; isto se dá, com efeito,

de tornar perene a obra de Cristo, o Pastor eterno. [...] Os Bispos, portanto, pelo Espírito Santo, que lhes foi dado, foram constituídos verdadeiros e autênticos Mestres da Fé, Pontífices e Pastores”. O itálico é nosso.

${ }^{5}$ Cf. também LG 21b: “... os Bispos, de maneira eminente e visível, fazem as vezes do próprio Cristo, Mestre, Pastor e Pontífice e agem em Seu nome”. Ou ainda: LG 27a: "Como vigários e legados de Cristo, os Bispos governam as Igrejas particulares que lhes foram confiadas, ...". Cf. também Presbyterorum Ordinis (PO) $7 \mathrm{~b}$.

${ }^{6}$ Cite-se também LG 24a: "Como sucessores dos Apóstolos, os Bispos recebem do Senhor, a quem foi dado todo o poder no céu e na terra, a missão de ensinar a todos os povos e pregar o Evangelho a toda criatura, ...". Ou também LG 25a: “[Os Bispos] são os mestres autênticos dotados da autoridade de Cristo, que pregam ao povo a eles confiado a fé que deve ser crida e praticada. [...] Devem os fiéis acatar uma sentença sobre a fé e a moral proferida por seu Bispo em nome de Cristo, ...". Cite-se ainda LG 27c: "O Bispo, enviado pelo Pai de família para governar sua família, ...”. Ou ainda: Christus Dominus (CD) 13a: "Com especial cuidado, [os Bispos] se interessem pelos pobres e humildes, para cuja evangelização os mandou o Senhor".

${ }^{7}$ Neste particular, consulte-se o texto do CONCÍLIO VATICANO I, Const. Dogm. Pastor Aeternus: DS 3061. Veja-se, outrossim, a resposta dos bispos alemães a Bismarck, em 1875, sobre o modo correto de se interpretar o conteúdo de PA na questão precisa da jurisdição do Romano Pontífice, bem como a carta apostólica do Papa Pio IX dirigida aos mesmos bispos (Mirabilis illa constantia, de 4 de março de 1875): DS 3112-3117.

${ }^{8}$ Também LG 25c: "A infalibilidade prometida à Igreja reside também no Corpo Episcopal, quando, com o Sucessor de Pedro, exerce o supremo magistério". 
graças "à força e à pressão da comunhão" . Nunca a Tradição eclesial entendeu a infalibilidade como uma espécie de apanágio daqueles que, na Igreja, exercem o ministério hierárquico do ensino. $\mathrm{O}$ dogma da infalibilidade do magistério solene do Papa, proclamado no Vaticano I, é desta feita, no Vaticano II, explícita e convenientemente posto em relação com o magistério dos Bispos e situado no contexto da comunhão eclesial.

\section{Doutrina da colegialidade episcopal}

Dentro da ampla doutrina conciliar sobre o episcopado, situa-se o conceito de colegialidade episcopal ${ }^{10}$, não como algo meramente acidental ao ministério eclesial dos Bispos, mas como realidade que lhe é ínsita ${ }^{11}$. Com efeito, afirma o Concílio que "alguém é constituído membro do Corpo Episcopal pela sagração sacramental e pela hierárquica comunhão com o Chefe e os membros do Colégio" (LG 22a) ${ }^{12}$. O Concílio, ao trazer à baila a doutrina do episcopado, o fez resgatando a qualidade sacramental do mesmo: daí a menção explícita à "sagração sacramental". Facilmente percebe-se aqui o valor da comunhão colegial entre os Bispos como algo inerente ao episcopado, para que assim, mediante a comunhão dos Pastores entre si, mantenha-se firme e inabalável a unidade do Rebanho de Cristo. Ou seja, o múnus episcopal não pode ser exercido de outra forma que não seja colegial, pois é deste modo que os sagrados Pastores vivenciam e promovem, enquanto tais, a comunhão da Igreja dispersa por todo o orbe. Não por acaso, já nos primeiros séculos de sua história, a Igreja soube rechaçar todo e qualquer risco de divisão que partisse do grêmio dos Pastores, para que assim se garantisse a integridade da comunhão eclesial ${ }^{13}$. A propósito disto, eis o que afirma o Concílio: "a índole

${ }^{9}$ Y. CONGAR, Vraie et fausse réforme dans l'Église, Paris: Cerf, 21968, p. 242.

${ }^{10}$ Para uma brevíssima nota histórica sobre a introdução do tema da colegialidade na LG, consulte-se P. EYT, "La collégialité", op. cit., pp. 539-541.

${ }^{11}$ Cf. J. RATZINGER, O novo povo de Deus, São Paulo: Paulinas, 1974, p. 169: "O colégio dos bispos não é uma simples invenção ou criação do papa, mas ele busca a sua origem em um ato sacramental e é por isso uma parte indispensável da estrutura da Igreja. A colegialidade dos bispos nasceu, portanto, quando nasceu a Igreja".

${ }^{12}$ Cf. também CD 4a. Veja-se, a propósito, J. RATZINGER, «El sacramento del orden como expresión sacramental del principio de tradición», in ID., Teoría de los principios teológicos. Materiales para una teología fundamental, Barcelona: Herder, 1985, pp. 287301, aqui p. 293.

${ }^{13}$ Convém recordar aqui, à guisa de nota histórica, as constantes polêmicas de Agostinho de Hipona com os Bispos donatistas, censurando-lhes o pecado de dividir o Rebanho de Cristo, quando deveriam, juntos aos bispos da Catholica, apascentar o Rebanho de Cristo "no único Pastor". É o que Santo Agostinho deixa transparecer, por exemplo, neste texto homilético: “Quais são as minhas ovelhas?', pergunta Cristo, 'ouçam a minha voz e me sigam'. Nestas palavras descubro que todos os bons pastores estão no único Pastor. Com efeito, não é verdade que faltem bons pastores: estes se encontram no único Pastor. Os outros, dado que divididos, são muitos. Aqui, entre nós, prega-se um único Pastor, porque é recomendada a unidade. [...] Mas todos os bons pastores estão no único [Pas 
e o caráter colegial da ordem episcopal são expressas já pela disciplina muito antiga segundo a qual os Bispos de todo o mundo tinham comunhão entre si e com o Bispo de Roma no vínculo da unidade, caridade e paz, como também pelos Concílios reunidos nos quais se resolviam em comum as questões importantes, auscultando ponderadamente a opinião de muitos. O mesmo é comprovado abertamente pelos Concílios Ecumênicos celebrados no decurso dos séculos. Da mesma forma também o insinua o antiqüíssimo costume de convocar vários Bispos para participarem da elevação de um neo-eleito ao ministério do sumo sacerdócio" (LG 22a) ${ }^{14}$.

No Colégio Episcopal, o papel do Bispo de Roma - ele mesmo membro do Colégio - é, e sempre será, imprescindível. O Colégio Episcopal, sem nele estar incluído o Romano Pontífice, não goza de nenhuma autoridade. Ao exprimir, mediante a diversidade dos Bispos, a variedade e a universalidade do Povo de Deus, o Colégio Episcopal tem no Sucessor de Pedro aquele que, ao interior do grêmio dos Bispos, faz-se vínculo e garante da unidade do mesmo Colégio (cf. LG 22b). Por sinal, "o Romano Pontífice [...] é o perpétuo e visível princípio e fundamento da unidade quer dos Bispos quer da multidão dos fiéis" (LG 23a). Entende-se, portanto, o papel necessário e insubstituível da Sedes romana, porém a ser devidamente situado no amplo contexto da vida eclesial, ou mais concretamente, no conjunto das Igrejas particulares presentes por todo o orbe. Trata-se de um ponto fixo no circuito de comunhão entre todas as Igrejas, de tal modo que lhes

tor], e constituem assim a unidade. Eles apascentam, é Cristo que apascenta. [...] Portanto [Cristo] apascenta, quando [os pastores em comunhão com Ele] apascentam, e diz: 'Eu apascento', enquanto neles faz-se presente a sua voz e a sua caridade. [...] Todos os pastores estejam portanto no único Pastor e emitam a sua única voz, de tal modo que as ovelhas ouçam esta única voz e sigam o seu Pastor, e não este ou aquele, mas o único. E todos n'Ele emitam uma única voz; não tenham diversas vozes" (Sermones ad populum 46, 29s: PL 38,288). A propósito desta questão, citemos também duas passagens de uma carta de Cipriano de Cartago: "A esta Igreja nós presidimos; é em prol de sua honra e de sua unidade que nós combatemos; é a sua graça e a sua glória que nós defendemos. Nós, com a divina permissão, regamos o sedento Povo de Deus; nós guardamos as fontes da vida.

Se, portanto, mantemos nossos direitos de posse, se reconhecemos o sacramento da unidade, por que nos fazemos prevaricadores da verdade, por que nos fazemos traidores da unidade? A água da Igreja, fiel, saudável, santa, não pode ser corrompida e adulterada, assim como a própria Igreja é incorruptível, casta e pudica" $(E p .73,11,2)$; "Tanto quanto nos é possível, não contendemos a respeito dos hereges com nossos colegas e com aqueles que são, como nós, bispos. Conservamos com eles a divina concórdia e a paz do Senhor. [...] Com paciência e doçura, nós mantemos a união dos corações, a honra do colégio, o vínculo da fé, a concórdia dos sacerdotes" ( $E p .73,26,2)$. A propósito deste tema, diga-se que freqüentemente a Igreja "viu nos promotores de cisma ou de heresia um grande orgulho e muito amor próprio" (Y. CONGAR, Vraie et fausse réforme, op. cit., p. 248).

${ }^{14}$ Veja-se também CD 36a. 
seja garantida a unidade no amor. O primado do Bispo de Roma, portanto, supõe a comunhão das Igrejas, bem como a promove. À Igreja de Roma é atribuída, desta forma, uma qualidade autenticamente sacramental: compete-lhe ser sinal eficaz de comunhão de toda a Igreja de Deus, que se faz presente, ao redor de todo o globo terrestre, em localidades as mais diversas. Se o Senhor Jesus chama a si doze homens para estarem com ele e enviá-los em missão (cf. Mc 3,13-19; 6,7-13; Mt 10,1-4; Lc 6,12-16), também constitui a um deles como rocha (cf. Mt 16,18; Jo 21,15-17) ${ }^{15}$. Ou seja, esta rocha - um ponto fixo, cuja solidez é garantida não pelas pretensões humanas (cf. Mc 14,29; Mt 26,33), mas pela presença animadora do Senhor Ressuscitado (cf. Jo 21,15ss) - foi constituída por Jesus como sinal de que ele, o Senhor, é o fundamento último sobre o qual se edifica a única e sempre una Igreja (cf. Ap 21,14; Ef 2,20) ${ }^{16}$.

Apoiado nas conclusões de estudos de exegese bíblica na década de 1960, o Concílio Vaticano II lembra a origem evangélica do Colégio Episcopal no chamamento que Jesus dirigiu a doze homens por ele escolhidos. Por conseguinte, é na colegialidade apostólica que a colegialidade episcopal encontra as suas raízes e o seu modelo ${ }^{17}$. Com efeito, assevera o Concílio que "estes Apóstolos (cf. Lc 6,13) [o Senhor Jesus] instituiu-os à maneira de colégio ou grupo estável, ao qual prepôs Pedro escolhido dentre os mesmos (cf. Jo 21,15-17)" (LG 19) ${ }^{18}$. Os Apóstolos, por sua vez, instituíram sucessores, a fim de que o Evangelho continuasse a ser anunciado "até ao fim dos tempos" (cf. Mt 28,20). Garante-se desta forma a transmissão do conteúdo essencial da fé cristã, mediante o ininterrupto processo da tradição apostólica (cf. LG 20a-b). Ainda que a transmissão deste conteúdo seja obrigação de todos os membros da Igreja (fiéis e pastores), ela é compromisso, sobretudo, daqueles que, na qualidade de sucessores dos Apóstolos (cf. LG 18b, 20a-c, 22b), são investidos do múnus episcopal.

\section{Solicitude por toda a Igreja}

Como assevera o Concílio, cada Bispo exerce o seu regime pastoral no âmbito da Igreja particular que lhe é respectiva ${ }^{19}$. Todavia, "enquanto membro do Colégio Episcopal e sucessor legítimo dos Apóstolos, cada qual, por

\footnotetext{
${ }^{15}$ Cf. LG 20c.

${ }^{16}$ Cf. LG 19.

${ }^{17}$ Cf. S. LYONNET, "A Colegialidade Episcopal e seus Fundamentos Escriturísticos", in G. BARAÚNA (org.), A Igreja do Vaticano II, Petrópolis: Vozes, 1965, pp. 821-838, aqui p. 821.

${ }^{18}$ Cite-se também LG 22a: "Assim como por disposição do Senhor São Pedro e os outros Apóstolos constituem um Colégio Apostólico, paralelamente o Romano Pontífice, Sucessor de Pedro, e os Bispos, Sucessores dos Apóstolos, estão unidos entre si”.

${ }^{19}$ Cf. CD 3b, 8 a.
} 
instituição e preceito de Cristo, é obrigado a ter solicitude pela Igreja universal" (LG 23b) ${ }^{20}$. Precisa o Concílio, contudo, que a solicitude para com a Igreja universal por parte dos Bispos não consiste num ato de jurisdição, muito embora seja "de grandíssimo proveito para a Igreja universal" (ibid.), pois o que está em jogo aqui é o empenho pela obra da evangelização como um todo (cf. CD 6b). Segundo o Concílio, portanto, a solicitude por todas as Igrejas não é obrigação exclusiva do Bispo de Roma: ela concerne a todos os membros do Corpo Episcopal.

\section{Experiência de comunhão}

O que está à base da doutrina conciliar da colegialidade episcopal é o conceito tradicional de Igreja mistério (ou sacramento) de comunhão ${ }^{21}$. Recorde-se que as longas e exaustivas discussões dos Padres conciliares sobre a natureza da Igreja evoluíram, de uma consideração excessivamente jurídica, para uma concepção "mistérica" (sacramental) da mesma. O esquema inicial proposto em vista da elaboração da Constituição Dogmática sobre a Igreja, redigido pela comissão teológica preparatória, foi rejeitado por um número considerável de Padres, exatamente pelo fato de sua redação ter sido marcada antes pelos aspectos jurídico-organizacionais da Igreja do que pelos dados da Escritura e da Tradição (especialmente da Patrística e da Liturgia ${ }^{22}$. Em Lumen gentium não se fala da constituição hierárquica da Igreja, senão depois que os dois primeiros capítulos do mesmo documento conciliar apresentem, respectivamente, a Igreja enquanto mistério (sacramento) e a sua conformação como Povo de Deus. É clara a opção dos Padres conciliares por situar o governo hierárquico, aí compreendida a colegialidade episcopal, no conjunto da vida da Igreja. Ou seja, o governo hierárquico, exercido colegialmente, está em função do bem e do progresso dos fiéis de todas as Igrejas particulares, com ressonâncias no bem de

\footnotetext{
${ }^{20}$ Também em CD 3a: "Partícipes da solicitude de todas as Igrejas, [os Bispos] exercemna em comunhão e sob a autoridade do Sumo Pontífice, no que se refere ao magistério e regime pastoral, unidos todos em Colégio ou corpo, com relação à Igreja universal de Deus”. Consultem-se ainda as passagens seguintes: CD 6a, $23 \mathrm{~d}$.

${ }^{21}$ Ainda que a título de mera ilustração, vale a pena mencionar a concepção de vivência eclesial enquanto comunhão divinizante entre Deus e o homem, característica da teologia ortodoxa: P. EVDOKIMOV, "Les principaux courants de l'ecclésiologie orthodoxe au XIXe siècle”, in M. NÉDONCELLE et al. (org.), L'ecclésiologie au XIXe siècle, Paris: Cerf, 1960 , pp. 57-76, aqui p. 62: "Na sua gênese, a Igreja remonta ao momento da criação do mundo; o mundo foi criado em vista da Igreja. [...] Philatério situa a Igreja no Paraíso. Deus vem, no 'frescor do dia', conversar com o homem, e a essência mesma da Igreja é esta comunhão divinizante entre Deus e o homem [cf. Gn 3,8] [...] É em função desta eclesialidade da existência que o homem devia responder, no seu próprio ser e livremente, ao Amor divino".

${ }^{22}$ Para um testemunho sobre as mudanças de concepção eclesiológica que se deram no desenrolar do Concílio, veja-se Y. CONGAR, Mon journal du Concile, Paris: Cerf, 2002, v. I, pp. 135, 274, 294, 297, 333, 334, 343.
} 
todos os homens, indistintamente. Ademais, não por acaso o capítulo terceiro de Lumen gentium inicia-se com a referência à instituição da Igreja, pelo Senhor Jesus, como diversidade de ministérios, entre os quais se encontra aquele do poder sagrado para o serviço de toda a comunidade eclesial: "Para apascentar e aumentar sempre o Povo de Deus, Cristo Senhor instituiu na Sua Igreja uma variedade de ministérios que tendem ao bem de todo o Corpo. Pois os ministros que são revestidos do sagrado poder servem a seus irmãos para que todos os que formam o Povo de Deus e portanto gozam da verdadeira dignidade cristã, aspirando livre e ordenadamente ao mesmo fim, cheguem à salvação" (LG 18a). O ministério dos Bispos, portanto, é exercido na Igreja como serviço de governo, de magistério e de santificação de todo o Povo de Deus, em vista do incremento da comunhão vivida entre os que seguem a Cristo. Em suma, na síntese eclesiológica do Vaticano II, a teologia da comunidade precede a teologia dos ministérios, opção metodológica que revela o escopo conciliar de orientar o ministério episcopal ao serviço de toda a Igreja.

Os sagrados Pastores encontram no Povo de Deus o espaço vital no qual se nutrem e se fortalecem. Uma vez alimentados nesta comunhão com os fiéis, os Bispos colegialmente, tendo o Bispo de Roma como Cabeça e Chefe do Colégio, desempenham mais plenamente o serviço do governo hierárquico da Igreja. Ou mais precisamente: é na comunhão eclesial (in medio Ecclesiae, na bela e feliz expressão dos Padres da Igreja) que os Bispos são robustecidos pelo Espírito do Ressuscitado, pois o Espírito, além de ser o agente último da comunhão eclesial, faz da comunidade eclesial mediação de sua presença e ação ${ }^{23}$. Portanto, é da tensão construtiva entre o ministério do pastoreio e os demais ministérios (presbíteros e diáconos, e leigos) que a Igreja de Cristo, animada pelo Espírito Santo, realiza sua peregrinação neste mundo em demanda da Casa do Pai. Nunca é demais repetir que o Concílio, propositadamente, parte da concepção da Igreja como comunhão de ministérios, e em seguida considera o ministério específico do governo hierárquico. Assim fazendo, o Vaticano II situa o ministério episcopal e, por conseguinte, a colegialidade episcopal, no amplo contexto da comunhão eclesial, e a serviço da mesma ${ }^{24}$.

${ }^{23}$ Cf. JOÃO PAULO II, Carta Apostólica sob forma de motu proprio "Apostolos suos", 8b: "Tal comunhão, que se alastra por toda a Igreja, dá forma também ao Colégio episcopal, ...". ("Talis communio, eo quod totam Ecclesiam pervadit, episcopale etiam Collegium conformat, ..." [in AAS 90 (1998) 647]). O itálico é nosso.

${ }^{24}$ Cf. Y. Congar, Jalons pour une théologie du laïcat, Cerf, Paris, 1953, p. 390s: "O princípio da colegialidade atua no interior da ordem hierárquica, mas ele se encontra, como princípio comunitário, no plano da Igreja toda. [...] [Na Igreja], o princípio hierárquico, determinante para estruturar, compõe-se, no exercício concreto da vida, com o princípio comunitário, que quer que todos sejam associados, segundo a ordem, a uma obra que não é [exclusiva] dos membros da hierarquia, mas da Igreja”. Veja-se também 
Se o múnus episcopal - exercido pelos Bispos em comunhão com o Papa - é praticado em função da vivência eclesial dos cristãos, decorre daí que a colegialidade se funda nesta vivência original do ser cristão como necessária experiência de comunhão, e comunhão vivida em torno de Cristo, "agente da paz e da unidade" (cf. Ef 2,14-16). Com efeito, Jesus "designou doze para estarem com ele e para os enviar a pregar e a exercer a autoridade de expelir demônios" (Mc 3,14s). Aliás, cabe recordar aqui a famosa dialética agostiniana entre "ser cristão com os cristãos" e "ser Bispo para os cristãos": Agostinho se reconhece membro da Igreja, e no interior da mesma, exerce o múnus episcopal para o bem dos irmãos. É no seio da Igreja - aliás, venerada por ele como mãe - que o Santo de Hipona conhece "a beleza tão antiga e tão nova" que é Cristo (cf. Conf. 10,27), e é no interior dela que ele exerce a sua missão de Bispo. Nada mais estranho, destarte, do que um Bispo que não se sinta filho da Igreja, que não tenha aprendido dela, nas muitas e diversas relações tecidas pela experiência da comunhão, a conhecer e a amar Cristo, e a se sentir impelido a anunciá-lo aos homens (cf. 1Cor 9,16; Tt 1,1).

A prática da colegialidade, por parte dos sucessores dos Apóstolos, nada pode ser senão a experiência convicta de que a Igreja é, essencial e necessariamente, comunhão. Não por acaso o princípio sinodal - ou conciliar era tão caro à Igreja antiga ${ }^{25}$, como o é atualmente. A prática da colegialidade autêntica - como sempre a entendeu a Igreja na sua história bimilenar -, por parte dos Bispos todos em comunhão com o Sucessor de Pedro, não deixa lugar à tentação da busca de privilégios, nem à da competitividade, nem à do carreirismo, realidades estas que comprometem seriamente a unidade do Rebanho do Senhor. A demonstrar esta verdade, os exemplos históricos não são poucos.

\section{Conferências Episcopais}

O Colégio Episcopal, quer reunido solenemente em Concílio Ecumênico, quer tendo os seus membros dispersos por toda a terra (cf. LG 22b; CD 4ab), encerra a totalidade daqueles que são marcados pelo caráter episcopal. A colegialidade episcopal, destarte, é necessariamente assinalada pela universalidade. Contudo, as Conferências Episcopais - que reúnem, cada qual, parte do episcopado mundial, e que, portanto, não constituem distintos "colégios episcopais" 26 têm papel fundamental no exercício da

B. SESBOÜÉ, "Les Conférences épiscopales en question", in IDEM., Le magistère a l'épreuve. Autorité, vérité et liberté dans l'Église, Paris: Desclée de Brouwer, 2001, pp. 223-242, aqui p. 225.

${ }^{25}$ A propósito, leia-se A. DI BERARDINO, "Percursos de koinonia nos primeiros séculos cristãos”, Concilium, n ${ }^{\circ} 291$ (2001) 46-61.

${ }^{26}$ Cf. JOÃO PAULO II, Apostolos suos, $12 \mathrm{~b}$. 
colegialidade. Elas são apresentadas pelo Concílio como formas atuais de se experimentar, num dado contexto geográfico, como outrora na Antigüidade, a "variedade de Igrejas locais com comum aspiração", razão pela qual "podem hoje contribuir com múltipla e fecunda força para que o afeto colegial seja levado a uma aplicação concreta" (LG 23d). Exatamente por congregar Bispos de um mesmo país, ou de países limítrofes numa mesma região do planeta, podem elas favorecer mais freqüentemente a experiência de comunhão e de solicitude dos Pastores por toda a Igreja de Cristo (cf. CD 37a, 38a). As assembléias "em tempos determinados" (CD 37a) de cada Conferência de Bispos, bem como as relações que se estabelecem "entre as Conferências Episcopais de diversas nações" (CD 38g) são de grande valor para o exercício da colegialidade episcopal, embora repitamos que elas, como tais, não constituem "colégios episcopais parciais"27. Não poderia ser de outro modo, pois o que está à base do princípio da colegialidade episcopal é justamente a preservação da unidade da Igreja de Cristo presente por todo o orbe ${ }^{28}$, na variedade de povos e línguas, costumes e culturas, ritos e sínteses teológicas.

Não se pode negar a importância que ganharam as Conferências Episcopais nos últimos tempos. Elas nasceram da iniciativa espontânea de alguns episcopados no século XIX. Através do motu proprio "Ecclesiae Sanctae", de 1966, o Papa Paulo VI impôs a sua formação onde elas ainda não existiam. Corre-se o risco, contudo, de considerá-las como meros "prolongamentos" da autoridade pontifícia, o que significaria um certo esquecimento do magistério conciliar ${ }^{29}$. Ora, se ao "completar" o Vaticano I, o que quis o Vaticano II, ao explicitar em especial a doutrina sobre o episcopado, foi justamente harmonizar primado e colegialidade, não é hora de se dar às Conferências Episcopais uma maior liberdade de expressão e de atuação? Dadas as diferenças de lugares e circunstâncias, num mundo cada vez

${ }^{27}$ Um colégio episcopal "à parte" configuraria um caso de cisma, como atestam fatos da História da Igreja.

${ }^{28}$ Cf., a propósito, J. RATZINGER, O novo povo de Deus, op. cit., p. 170: "O poder do bispo é e deve ser exercido colegialmente, pois está, por sua própria natureza, a serviço da unidade da Igreja, a qual não é apenas uma organização cujas diretrizes vêm do alto, mas uma comunhão horizontal, da qual participam todos os que vivem da fé". Ibid., p. 171: "A unidade da Igreja requer a estrutura do colégio como representação das Igrejas e de sua comunhão interna".

${ }^{29}$ Sobre a relação entre o magistério pontifício e aquele dos Bispos, citemos B. SESBOÜÉ, "La notion de magistère dans l'histoire de l'Église et de la théologie", in IDEM, Le magistère à l'épreuve. Autorité, vérité et liberté dans l'Église, Paris: Desclée de Brouwer, 2001, pp. 17-61, aqui p. 53: "Antes de tudo, há a questão prática da relação entre o magistério pontifício e aquele dos bispos, fora da reunião conciliar. Estes bispos não estão mais, hoje em dia, completamente 'dispersos', uma vez que estão reagrupados em Conferências episcopais que funcionam regularmente. [...] Importa que o fundamento colegial e sinodal das Conferências episcopais, que se reúnem sempre em comunhão com a Sé de Roma, seja claramente reconhecido e possa ser exercido em pleno respeito à estrutura da Igreja que associa a colegialidade à presidência pessoal". 
mais complexo como o nosso ${ }^{30}$, a indicação à Sé romana de candidatos ao episcopado, por exemplo, não poderia ser uma tarefa ordinária das Conferências Episcopais, como manifestação de comunhão e de sensibilidade frente aos problemas pastorais regionais? ${ }^{31}$

A busca do bem da Igreja universal é o que deve motivar as relações entre os Bispos de uma determinada Conferência, uma vez que o Concílio situa as Conferências de Bispos "no horizonte da unidade e/ou da comunhão eclesiais em nível nacional, supranacional e universal"32. É aqui, propriamente, que se deve praticar o diálogo entre Bispos que vivem problemas e inquietações comuns, porque estão à frente de dioceses vizinhas, para que a manifestação de tais problemas e inquietações por eles suscitados cheguem à Sé Romana após um certo processo de reflexão comum em vista de uma objetiva, sensata e amadurecida consideração dos mesmos ${ }^{33}$. A busca humilde de soluções para os problemas que afligem homens e mulheres de hoje, feita sempre na docilidade ao Espírito Santo e em comunhão com os seus pares por parte de homens "que não se julgam serem sempre competentes a ponto de terem solução concreta e imediata para toda questão" (Gaudium et Spes 43b), por si só constitui um sinal, para o mundo, de esperança no Senhor da história ${ }^{34}$. Ou ainda, o respeito e o

${ }^{30}$ Cf. B. SESBOÜÉ, "Les Conférences épiscopales en question”, op. cit.,p. 226: "Hoje em dia, mais e mais se verifica que um bispo não é mais capaz, a título pessoal, de fazer face à complexidade dos problemas que lhe são colocados, que as fronteiras entre dioceses nunca foram tão porosas e que decisões e orientações doutrinais comuns se impõem a uma evangelização crível".

${ }^{31}$ A propósito disto, parece-nos ainda válida a recomendação feita pelos Bispos reunidos no Vaticano II e inserida no Decreto Christus Dominus: "Desejam os Padres do Sacrossanto Concílio que [os] Dicastérios [...] sejam submetidos a uma reestruturação, mais adaptada às necessidades dos tempos, regiões e ritos, principalmente no que diz respeito ao número, nome, competência e à própria razão de proceder e à coordenação dos trabalhos entre si. Desejam ainda que, em vista do múnus pastoral próprio dos Bispos, o ofício dos Legados do Pontífice Romano seja mais exatamente determinado" (CD 9b). Quanto a mudanças e alterações das dioceses, recomendam os Padres conciliares que as Conferências Episcopais sejam também ouvidas: cf. CD 24. ${ }^{32}$ A. ANTÓN, "La carta apostólica MP “Apostolos Suos"' de Juan Pablo II: Se reafirman algunos puntos claves, mientras otros quedan abiertos a la investigación teológica y canónica”, Gregorianum 80, 2 (1999) 263-297, aqui p. 268. O itálico é do autor. Cf. ibid., p. 270.

${ }_{33}$ Entre prelados, há o temor de que as Conferências se interponham de modo pouco conveniente entre o Bispo diocesano e a Santa Sé, quando na verdade elas são instrumentos eficazes de intermediação entre ambas as instâncias. Não se pode afirmar que este temor é infundado; porém, "o abuso não suprime o uso" (abusus non tollit usum): cf. J.R. QUINN, Reforma do Papado. Indispensável para a unidade cristã. Aparecida: Santuário, 2002, p. 119. Ademais, reconheça-se que as tensões entre as Conferências e a Sé Romana são normais: as tensões são "lei da vida". Consultem-se a propósito A. ANTÓN, "La carta apostólica MP ‘Apostolos Suos”', art. cit., pp. 281, 283, 290; B. SESBOÜÉ, "Les Conférences épiscopales en question”, pp. 228-230, 234, 236, 242.

${ }^{34}$ Por certo, são pertinentes aqui as seguintes palavras de W. KASPER, "Die Kirche als Ort der Wahrheit", in IDEM, Theologie und Kirche, Mainz: Matthias-Grünewald, 1987, 
acatamento da autoridade da Sé romana - autoridade esta sempre situada no conjunto das Igrejas particulares e em função, precipuamente, da unidade eclesial - não exclui que se discutam questões e que se tomem decisões no âmbito de competência das Conferências Episcopais. Tratarse-ia aqui da aplicação do ainda muito discutido "princípio da subsidiariedade"? Quando as Conferências de Bispos discutem questões que lhes são concernentes e tomam resoluções a partir daí, não seriam desejáveis uma maior confiança e uma maior transparência por parte da Sé romana? ${ }^{35}$

Soa atual a seguinte sugestão do Sínodo dos Bispos de 1985: estude-se o estatuto teológico das Conferências Episcopais, "para que em particular a questão de sua autoridade doutrinal seja mais claramente e mais profundamente explicitada" (Síntese dos trabalhos da assembléia sinodal, 8b). Em resposta a este pedido dos Bispos presentes ao Sínodo de 1985, chegou-se a algumas conclusões, porém em âmbito quase que exclusivamente jurídi$\mathrm{CO}^{36}$. Na esfera da reflexão teológica propriamente dita, ainda é necessário seguir adiante ${ }^{37}$, sobretudo quanto ao papel que as Conferências Episcopais possam ter no que diz respeito ao munus regendi e ao munus docendi das Conferências como tais (ou seja, como "sujeitos coletivos"), e não de cada Bispo em pessoa ${ }^{38}$. A pergunta fundamental que se coloca nesta discussão é a seguinte: declarações doutrinárias das Conferências Episcopais têm força vinculante? O Papa João Paulo II, através do motu proprio Apostolos Suos, responde que sim, porém as condições impostas são bastan-

pp. 255-271, aqui p. 268: "A busca da verdade na Igreja deve dar-se na forma de diálogo. Enquanto sacramento do diálogo de Deus com o mundo, a Igreja é estruturada em si mesma em modo dialógico". E ainda, à p. 271: "Esta estreita interdependência entre verdade e amor é a mais profunda razão pela qual a comunidade eclesial é o lugar da verdade. Porque lugar da verdade, a Igreja é, no mundo, sinal profético e instrumento da unidade, da paz e da reconciliação".

${ }^{35}$ No afã de manifestar a preocupação do Papa pela unidade da Igreja, o motu proprio Apostolos suos acaba por ter em menor conta a diversidade que há na profusão de Igrejas particulares. Cf. A. ANTÓN, "La carta apostólica MP “Apostolos Suos", art. cit., p. 271. Veja-se também P. TIHON, "L'Église", in B. SESBOÜÉ (org.), Les signes du salut, Paris: Desclée, 1995, pp. 339-561 (Col. Histoire des Dogmes, v. 3), aqui p. 538.

${ }^{36}$ A Carta Apostólica do Papa João Paulo II sob forma de Motu proprio, Apostolos suos [21/maio/1998], promulgada quase treze anos após o encerramento do Sínodo dos Bispos de 1985 e que consiste na resposta às aspirações nele manifestadas sobre a natureza e a utilidade das Conferências Episcopais, apresenta-se mais exatamente como texto legislativo do que teológico-eclesiológico. Não se poderia dizer que Apostolos suos consiste num conjunto de normas complementares sobre as Conferências Episcopais (4 pequenos artigos no último capítulo) precedido de uma longa introdução (três capítulos)?

${ }^{37}$ Quanto à reflexão sobre o estatuto teológico das Conferências Episcopais, o motu proprio de João Paulo II, Apostolos suos, na verdade, deixa caminhos abertos às pesquisas. A propósito, cf. A. ANTÓN, "La carta apostólica MP 'Apostolos Suos", art. cit., pp. 266-268, 272, 291, 293, 295.

${ }^{38}$ Cf. A. ANTÓN, "La carta apostólica MP “Apostolos Suos”, art. cit., p. 274. 
te exigentes: “... é necessário que sejam aprovadas por unanimidade dos membros Bispos, ou então, quando aprovadas na reunião plenária ao menos por dois terços dos Prelados que pertencem à Conferência com voto deliberativo, que obtenham a revisão (recognitio) da Sé Apostólica" ${ }^{\prime 39}$. Sem dificuldade se entende a exigência de unanimidade, uma vez que se quer garantir o munus docendi de cada Bispo em particular; porém, especialmente em se tratando de Conferências Episcopais numerosas, este critério seria realista? ${ }^{40}$

\section{Sínodo dos Bispos}

Algo seja dito do Sínodo dos Bispos, instituído por Paulo VI em setembro de 1965, mediante o motu proprio Apostolica Sollicitudo. Muito embora não se constitua como "colégio episcopal", o Sínodo dos Bispos, contudo, em razão de seu caráter de representatividade e pelo fato de ser convocado pelo Romano Pontífice, consiste num importante instrumento de exercício da colegialidade, mormente na colaboração junto à Santa Sé em vista da solicitude para com a Igreja universal (cf. CD 5) ${ }^{41}$.

Uma vez reconhecido o seu valor e utilidade, todavia deve-se admitir que a forma segundo a qual o Sínodo dos Bispos realiza-se, hoje, na Igreja católica romana, não contribui para que se incremente a comunhão entre as Igrejas particulares. A participação de membros da Cúria romana no Sínodo dos Bispos, por exemplo, não acaba por inibir a manifestação livre e franca dos prelados convocados? No caso particular dos sínodos nacionais ou regionais, não é questionável que eles se realizem freqüentemente em Roma? Deve-se admitir que, realizado desta forma, o Sínodo dos Bispos tem promovido mais o fortalecimento da figura do Papa do que a comunhão entre as Igrejas diocesanas ${ }^{42}$.

\footnotetext{
${ }^{39}$ Apostolos Suos, art. $1^{\circ}$ das Normas Complementares; cf. Apostolos Suos 22.

${ }^{40}$ Consulte-se a propósito B. SESBOÜÉ, "Les Conférences épiscopales en question", op. cit., p. 240. Para uma demonstração da complexidade dos debates teológicos em torno ao estatuto teológico das Conferências Episcopais, cf. B. MALVAUX, "Un débat toujours actuel: le statut théologique des conférences des évêques", NRTh $123 / \mathrm{n}^{\circ} 2$ (2001) 238253, aqui pp. 242-248. Veja-se também A. ANTÓN, "La carta apostólica MP 'Apostolos Suos", art. cit., pp. 286, 294.

${ }^{41}$ Numa nova configuração de Igreja, onde houvesse menos centralização da Sé romana e mais participação das Igrejas diocesanas na pessoa dos prelados, uma contribuição significativa do Sínodo dos Bispos, convocado pelo Papa com certa regularidade, seria propriamente aquela de preparar a agenda de um possível futuro Concílio, de tal forma os Padres conciliares chegassem à assembléia conciliar com uma série de questões previamente estudadas e amadurecidas. Veja-se, a propósito deste tema, J. R. QUINN, Reforma do Papado, op. cit., p. 125.

${ }^{42}$ Consulte-se a propósito P. TIHON, "L’Église", op. cit., p. 532.
} 


\section{Frutos da prática da colegialidade}

Se a vivência da colegialidade por parte dos Bispos unidos ao Romano Pontífice funda-se na comunhão eclesial garantida pelo Espírito de Cristo e, ao mesmo tempo, trata-se de um dinamismo de promoção desta mesma comunhão, é natural que sua prática, ou sua ausência ou deficiência, não deixam de ter repercussões na vida eclesial como um todo. Passamos a referir alguns dos frutos da colegialidade episcopal.

\section{A unidade da Igreja diocesana}

A coesão do clero em torno de seu respectivo Bispo, bem como a união dos fiéis numa determinada Igreja particular (cf. CD 16a, 17a) ${ }^{43}$, obviamente constituem um reflexo positivo da colegialidade episcopal. Com efeito, a unidade da Igreja diocesana constitui sinal da unidade de seu respectivo Pastor com os demais Pastores (cf. LG 23a), os quais, como vigários de Cristo, devotam-se colegialmente ao pastoreio do único e uno Rebanho do Senhor. Ora, é exatamente aqui que se nota mais claramente a qualidade sacramental do múnus episcopal exercido no Corpo dos Bispos: é na visibilidade da pessoa do Bispo como vínculo de unidade da Igreja diocesana que se manifesta a unidade de toda a Igreja de Cristo, pois "quando se trata da Igreja, a universalidade supõe a particularidade, e vice-versa" ${ }^{44}$. Em eclesiologia, portanto, "universalidade" e "particularidade" não se excluem, antes se exigem: somente se fazendo concreta num determinado lugar (numa parte) a Igreja pode ser sinal da reconciliação universal entre os homens realizada por Cristo (cf. Gl 3,28; $\mathrm{Cl} 3,11)^{45}$.

\section{Dinamização da Igreja diocesana}

A prática da colegialidade episcopal encoraja cada Bispo, em sua própria Igreja particular, a que exerça com alegria e disposição o nada fácil ministério de animação e dinamização da parte do Rebanho de Cristo a ele confiada. Tendo o seu coração alargado em prol de todas as Igrejas particulares, ele se engaja denodadamente no pastoreio de sua própria grei. Por sinal, no exercício do múnus específico de santificar, diz o

\footnotetext{
${ }^{43}$ Sobre a união dos presbíteros com os Bispos, cf. PO 7c, 15b; e dos presbíteros com os Bispos e os demais irmãos no sacerdócio, cf. PO 14c.

${ }^{44}$ P. EYT, "La collégialité", op. cit., p. 545.

${ }^{45}$ Cf. CD 11a: "[Na Igreja particular] verdadeiramente reside e opera a Una, Santa, Católica e Apostólica Igreja de Cristo". Recordem-se aqui os endereçamentos das cartas paulinas, quando o Apóstolo sempre se dirige às Igrejas que estão nas suas respectivas cidades ou regiões: $\mathrm{Rm} 1,7$; 1 Cor 1,2; 2 Cor 1,1; Gl 1,2; Fl 1,1; Cl 1,2; 1Ts 1,$1 ; 2 \mathrm{Ts} 1,1$.
} 
Concílio Vaticano II que os Bispos "de tal maneira santifiquem suas Igrejas que nelas resplandeça plenamente o senso da Igreja Universal de Cristo" (CD 15c). Quando um Bispo zela, amorosa e incansavelmente, pelo bem daqueles que lhe foram confiados pelo bom Pastor, estando à frente de uma sede episcopal ainda que localizada no mais inexpressivo e desimportante sítio, não estaria demonstrando uma real e frutuosa solicitude para com todas as Igrejas? ${ }^{46}$ Em suma, "regendo bem a própria Igreja como porção da Igreja universal, [os Bispos] contribuem eficazmente para o bem de todo o Corpo Místico, que é também o corpo das Igrejas" (LG 23b).

Mais: é o exercício da colegialidade, especificamente enquanto solicitude por todas as Igrejas praticada por cada Bispo, que sensibiliza e motiva os fiéis a que também eles, segundo as mais diversas vocações, se engajem na obra da evangelização enquanto atenção às necessidades da Igreja do Senhor $^{47}$, mormente em circunstâncias de grande provação ${ }^{48}$. É no zelo pastoral dos Bispos - que em razão da colegialidade ganha dimensão universal - que os fiéis encontrarão encorajamento para que eles também, a seu modo, se mostrem solícitos por toda a Igreja e, por conseguinte, se ponham a serviço dos homens e mulheres que padecem as mais diversas carênci$\mathrm{as}^{49}$. É o que se nota, por exemplo, no que tange às missões e a ajuda fraterna às Igrejas em situações difíceis (cf. LG 23c), com a correspondente motivação ao engajamento dos fiéis.

${ }^{46}$ Quando trata do múnus episcopal de santificar, assim se expressa o Concílio: "A Igreja de Cristo está verdadeiramente presente em todas as legítimas comunidades locais de fiéis, que, unidas com seus pastores, são também elas no Novo Testamento chamadas 'Igrejas'. [...] Nestas comunidades, embora muitas vezes pequenas e pobres, ou vivendo na dispersão, está presente Cristo, por cuja virtude se consorcia a Igreja una, santa, católica e apostólica" (LG 26a). Ainda nesta mesma direção, no que diz respeito ao modo de propor a doutrina cristã: "Com especial cuidado, [os Bispos] se interessem pelos pobres e humildes, para cuja evangelização os mandou o Senhor" (CD 13a). Ou ainda: Para que bem desempenhem o governo diocesano, os Bispos "esforçem-se para conhecer a fundo as necessidades nas circunstâncias sociais em que vivem [os fiéis]" (CD 16e).

${ }^{47}$ Cf. CD 6b: "[Os Bispos] empenhem-se com todo vigor para que as obras da evangelização e do apostolado sejam sustentadas e promovidas com entusiasmo pelos fiéis. Além disto esforcem-se por providenciar sejam preparados aptos ministros sacros e ainda auxiliares, tanto religiosos como leigos, em prol das missões e das regiões que sofrem de penúria de sacerdotes. Cuidem também que, na medida do possível, alguns dos seus sacerdotes se dirijam às referidas missões ou dioceses, ...”. Cf. ainda CD 6c: “... no uso dos bens eclesiásticos, os Bispos lembrem-se que devem considerar não só as necessidades de sua diocese, mas também as das outras Igrejas particulares, pois que são partes da mesma Igreja de Cristo".

${ }^{48}$ CD 6c: "[Os Bispos] cuidem [...] de aliviar o quanto possível as calamidades de que outras dioceses ou regiões estão sofrendo".

${ }^{49}$ Cf. Apostolicam Actuositatem 8d, 10c, 14c, 16c, 16g, 21. 
Quando se discute a colegialidade episcopal como força de dinamização da Igreja diocesana, algo se diga a respeito dos presbíteros. Uma vez que, mediante o ministério que lhes é peculiar, devem tornar visível a Igreja universal no lugar em que trabalham, e se dedicar à ação pastoral de toda a diocese e da Igreja de Cristo (cf. LG 28b), também nos presbíteros deve ser despertada e alimentada a solicitude por todas as Igrejas. Com efeito, "todos os sacerdotes, tanto os diocesanos como os religiosos, em razão da Ordem e do ministério, estão unidos com o Corpo dos Bispos e segundo sua vocação e graça devem servir ao bem de toda a Igreja" (LG 28b). Ora, é na vivência da colegialidade episcopal testemunhada por seus Bispos respectivos, que os presbíteros sentem-se motivados, eles também, a cultivar e viver o zelo pastoral pela Igreja de Cristo, que por sinal não se reduz aos limites da diocese, e muito menos da paróquia ${ }^{50}$. Além disso, a vivência da fraternidade que deve marcar as relações entre os presbíteros (cf. LG 28c; CD 28c, 30d, 30h; PO 8a-d, 10c, 17a, 22c), bem como a integração pessoal em meio às múltiplas tarefas que desempenham (cf. LG 28c; PO 14a), encontrarão exemplo e estímulo na manifestação colegial do múnus episcopal.

\section{Eucaristia e Igreja}

Na consideração dos frutos que decorrem da prática da colegialidade episcopal, não poderíamos deixar de mencionar o significado da Eucaristia para a vida eclesial, ela que é o sacramento que "faz a Igreja"51. Ao presidir a assembléia eucarística em sua respectiva sede (cf. LG 26b), o Bispo, em comunhão com seus irmãos no episcopado, está realizando um ato autenticamente colegial ${ }^{52}$. Ainda que celebrada num

\footnotetext{
${ }^{50}$ Cabe aqui citar uma recomendação do Concílio dada aos párocos: "No exercício desta cura [das almas] os párocos com seus coadjutores cumpram o ofício de ensinar, santificar e reger de tal modo que os fiéis e as comunidades paroquiais se sintam realmente membros, seja da diocese seja da Igreja universal" (CD 30b). Cite-se também PO 6d: "Para desenvolver [...] devidamente o espírito de comunidade, [o múnus de Pastor] há de atingir não só a Igreja local, mas toda a Igreja universal". Vejam-se ainda PO 10a, 11a, 11b; AA 10b.

${ }^{51}$ A propósito: CD 15b: "[Os Bispos] continuamente se esforcem por que os fiéis cristãos adquiram conhecimentos mais profundos do mistério pascal e o vivam pela Eucaristia, de modo que constituam um só Corpo estreitamente unido na união da caridade de Cristo". Sobre a centralidade da Eucaristia na vida dos presbíteros, cf. PO 6e.

${ }^{52}$ Cf. A. ANTÓN, "La carta apostólica MP “Apostolos Suos", art. cit., pp. 279-280: "A pertença do bispo ao colégio episcopal em virtude da realidade ontológico-sacramental de sua ordenação em comunhão com a cabeça, faz com que seus atos, ainda que pessoais em si mesmos, impliquem uma dimensão colegial, enquanto ele permaneça na comunhão hierárquica". O itálico é do autor. Veja-se também A. ANTÓN, "Le 'status' théologique des conférences épiscopales", in H. LEGRAND / J. MANZANARES / A. GARCÍA Y GARCÍA (org.), Les conférences épiscopales. Théologie, statut canonique, avenir. (Actes
} 
lugar preciso, fazendo-se uso de uma língua determinada, servindo-se de expressões culturais locais, é a Eucaristia o único e insuperável memorial da entrega de Cristo na cruz, quando então, levantado no madeiro, ele congregou todos os homens em torno de si (cf. Jo 12,32). Quando uma Igreja diocesana celebra a Eucaristia, sob a presidência de seu Bispo, ou de presbíteros por ele delegados para esta função precisa, manifesta-se então a única e sempre una Igreja de Cristo. Ora, isto se dá não apesar dos elementos culturais empregados na celebração, mas justamente através deles: é na diversidade destes elementos que se mostra a unidade da Igreja que, na metáfora de Agostinho, se veste de um manto de colorido variegado ${ }^{53}$.

A propósito do que se disse acima, não há como não lamentar a progressiva dissociação que se deu no Ocidente, a partir dos séculos XI e XII, entre "Igreja" e "Eucaristia". Em conseqüência, sobretudo, das controvérsias em torno ao tema da presença real de Cristo no sacramento da Eucaristia, passou esta a ser entendida como "corpo verdadeiro de Cristo", e a Igreja, como "corpo místico de Cristo". Ora, no primeiro milênio da Igreja, quando se dizia que a Eucaristia é o corpo místico (mistérico, ou sacramental) de Cristo, o sacramento do altar espontaneamente remetia a comunidade celebrante à síntese cristológico-eclesiológica paulina da Igreja entendida como "corpo de Cristo" (cf. Rm 12,5; 1Cor 10,16s; 1Cor 12,12.27). A tradicional diferenciação entre "corpo verdadeiro de Cristo" (Igreja) e "corpo místico de Cristo" (Eucaristia) tornava possível a intuição, por parte da comunidade cristã celebrante, do vínculo entre Eucaristia e Igreja, com as vantajosas conseqüências pastorais daí decorrentes $^{54}$.

du Colloque international de Salamanque, 3-8 janvier 1988), Paris: Cerf, 1988, pp. 253289, aqui p. 276.

${ }^{53}$ Veja-se AGOSTINHO DE HIPONA, Enarr. in ps. 44,24.

${ }^{54} \mathrm{Em}$ nossas assembléias eucarísticas hodiernas, não é ainda problemática a recepção da Eucaristia, por parte de não poucos fiéis, como acolhida do "doce hóspede das almas"? Mais: O que se pode dizer das celebrações da Eucaristia transmitidas pela televisão? Esta prática favorece a consolidação dos laços de unidade da Igreja particular em torno de seu respectivo Bispo? Ou antes a dificulta, na medida em que os fiéis, desta forma, não são ajudados a reconhecer, no Bispo que lhes é respectivo, aquele que está à frente da Igreja diocesana à qual eles pertencem? Ora, quando na anáfora o Bispo do lugar é citado, isto não se faz por mera honra, mas justamente para significar que, sob o munus santificandi daquele determinado Bispo, a Igreja local está em comunhão - a Eucaristia não é, por sinal, o sacramento da comunhão? - com todas as demais Igrejas particulares. O que está aqui em jogo é o próprio caráter sacramental do episcopado, pois cada Bispo, em pessoa, faz-se sinal da permanente presença do Cristo Pastor em sua Igreja. 


\section{Repercussões ecumênicas}

Não pode ser subestimada a vantagem ecumênica do exercício da colegialidade episcopal. Quando chama os Doze (cf. Mc 3,13-19; Mt 10,14; Lc 6,12-16), Jesus estabelece a nova e definitiva aliança entre Deus e os homens, e o faz, de modo particular, na forma de restauração da unidade das doze tribos de Israel. Com efeito, ele vem para reunir as ovelhas dispersas da casa de Israel (cf. Mt 15,24). Jesus sana, desta forma, as feridas da divisão do Povo eleito. Constitui a sua Igreja a partir de Israel; revela destarte que o Deus dos Patriarcas mantém-se fiel a sua promessa. Por conseguinte, a comunhão colegial dos Bispos, vivida particularmente como desvelo pela unidade do Rebanho de Cristo, não deixará de suscitar, tanto nos próprios Bispos como nos presbíteros, diáconos, religiosos e leigos, uma real sensibilidade frente aos apelos do ecumenismo contemporâneo: afinal, que compromisso revela-se fortemente no movimento ecumênico, senão a de dócil e confiantemente orar e trabalhar para que o bálsamo do Espírito de Cristo, hoje, cure as feridas da divisão do Corpo eclesial?

É hora de se recuperar uma das intuições de João XXIII, a saber, a da necessária renovação do modo de governo na Igreja católica romana. Tal renovação deve-se concretizar, enquanto testemunho para os cristãos não católicos, na renúncia a tudo que não seja essencial ao múnus pontifício e na recuperação da forma colegial do governo hierárquico da Igreja de Cristo $^{55}$. O Papa João Paulo II, por sua vez, em sua magnífica encíclica sobre o empenho ecumênico, Ut Unum Sint (UUS), estimulou a busca de uma forma de exercício do ministério petrino que seja condizente com a atual atmosfera ecumênica e que propicie a restauração da unidade visível

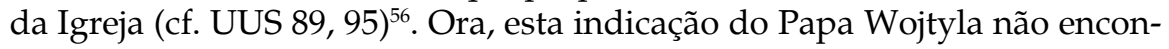
traria já, na efetiva prática colegial do ministério episcopal, uma ressonância significativa? ${ }^{57}$

55 É emblemático, a propósito, o testemunho apresentado por L. BOUYER, La décomposition $d u$ catholicisme, Paris: Aubier-Montaigne, 1968, p. 38: "Quando João XXIII, recém-eleito, saiu da capela Sistina, disse àqueles que o circundavam: 'Desejo que o meu pontificado restaure a colegialidade na Igreja”. Veja-se também Y. CONGAR, Mon journal du Concile, v. I, op. cit.,p. 321.

${ }^{56}$ São, por sinal, pertinentes as palavras de J. R. QUINN, Reforma do Papado, op. cit., p. 17: "Temos de encarar o fato que, em função da unidade cristã, a Igreja católica deverá fazer significantes mudanças estruturais, pastorais e canônicas. Colegialidade, participação do laicato, descentralização e maior abertura para a diversidade são obviamente as áreas nas quais a Igreja católica terá de mudar”.

${ }^{57}$ As dificuldades para o diálogo entre católico-romanos e ortodoxos, suscitadas pelo exercício de um papado forte na Igreja latina, podem, em parte, ser superadas por uma frutuosa prática da colegialidade episcopal entre os Bispos da mesma Igreja latina. A propósito, citemos Y. CONGAR, "J'aime l'orthodoxie", in IDEM, Essais œcuméniques. Le mouvement, les hommes, les problèmes, Paris: Le 
Sem sombra de dúvida, a prática da colegialidade nos aproximaria mais das Igrejas da Ortodoxia, bem como das Igrejas oriundas da Reforma protestante e da Igreja anglicana. Haja vista a grande consideração que têm tanto os cristãos orientais quanto os protestantes e anglicanos pela estrutura sinodal da Igreja. Católicos romanos e ortodoxos muito ganhariam com esta aproximação: aqueles, corrigindo-se dos excessos de um papado muito forte; e estes, do risco de uma extrema independência das Igrejas locais sem um centro de comunhão e unidade. Algo parecido diga-se também dos protestantes, que reconhecem os perigos de uma eclesiologia que advogue a ilimitada liberdade das comunidades locais, o que fatalmente conduz à divisão e ao estranhamento mútuo das mesmas.

\section{A apostolicidade da Igreja}

Outro valor cujo resgate pode ser favorecido por uma prática de governo hierárquico autenticamente colegial é o de uma compreensão mais lúcida, por parte de pastores e fiéis, do que significa dizer que a Igreja é apostólica. Ora, a Igreja é apostólica porque dá testemunho, a partir dos Apóstolos e ao longo dos séculos, de que Jesus é o Senhor (cf. Lc 24,34). A apostolicidade da Igreja nada significa senão que a transmissão da experiência de fé (consignada no querigma) e cujo início está na pregação dos Apóstolos, acontece ininterruptamente. Ora, esta transmissão da experiência de fé, a parádosis, iniciou-se na Igreja primitiva com o ministério da pregação. É o que encontramos em Paulo: “Irmãos, venho lembrar-vos o evangelho que vos anunciei, o qual recebestes e no qual ainda perseverais; por ele também sois salvos, se retiverdes a palavra tal como vo-la preguei, a menos que tenhais crido em vão. Antes de tudo, vos entreguei o que também recebi: que Cristo morreu pelos nossos pecados, segundo as Escrituras, e que foi sepultado e ressuscitou ao terceiro dia, segundo as Escrituras" (1Cor 15,1-4) $)^{58}$. Trata-se aqui de algo da mais grave importância, pois os Apóstolos são aqueles que fizeram uma experiência pessoal de Jesus e nos transmitiram não um mero conteúdo doutrinário, mas esta

Centurion, 1984, pp. 71-75, aqui p. 75: “A questão mais difícil é evidentemente aquela do papado, não a ponto ainda de ser resolvida. Há aberturas. [...] A abordagem dogmáticoteológica do Vaticano II sobre a colegialidade representa um evidente progresso de nossa parte com relação àquela do Vaticano I. Trata-se de um começo; a colegialidade será aquilo que dela fará a prática. Porém, é um começo importante, porque não pode haver uma prática que não se apóie numa certa teologia". Ou ainda: Y. CONGAR, "Cinquante années de recherches de l'unité", in IDEM, Essais œecuméniques, pp. 76-96, aqui p. 93 "Um papado tal como o fez a história, centralizador, imperial, estreitamente autoritário, não! Um ministério papal presidindo à comunhão e à unidade num regime colegial e conciliar, por que não?".

${ }^{58} \mathrm{Ou}$ também: "Porque eu recebi do Senhor o que também vos entreguei: ..." (1Cor 11,23). 
mesma experiência: "O que era desde o princípio, o que temos ouvido, o que temos visto com os nossos próprios olhos, o que contemplamos, e as nossas mãos apalparam, com respeito ao Verbo da vida - e a vida se manifestou, e nós a temos visto, e dela damos testemunho, e vo-la anunciamos, a vida eterna, a qual estava com o Pai e nos foi manifestada-, o que temos visto e ouvido anunciamos também a vós outros, para que vós, igualmente, mantenhais comunhão conosco" (1Jo 1,1-3). Assim agiram os Apóstolos para que, ao longo do tempo, perdurasse a comunhão eclesial não só por meio dos elementos institucionais da Igreja, mas sobretudo pela experiência - feita in Ecclesia por cada crente - de que Deus, de fato, fez morada entre os homens (cf. Jo 1,14) em "Jesus, nos dias de sua carne" (Hb $5,7)^{59}$. Ora, uma eclesiologia que considere seriamente a Igreja na sua nota de apostolicidade "deverá partir também da comunidade para explicar o processo da transmissão da revelação na Igreja. Os Apóstolos estão igualmente sujeitos a este movimento pendular de escutar e transmitir, de receber e dar dentro do mistério da comunhão da Igreja"60. Em suma, o exercício colegial do governo hierárquico da Igreja leva a despertar, entre fiéis e pastores, a consciência de que a Igreja é apostólica, isto é, ela se configura não só como comunhão de Igrejas (catolicidade espacial), mas também como comunhão com os que nos precederam na fé (catolicidade temporal $)^{61}$.

\section{Algumas lacunas na doutrina conciliar sobre a colegialidade episcopal}

O Vaticano II não deu respostas exaustivas a todas as questões ligadas à colegialidade episcopal, de modo particular no que diz respeito à articulação entre o ministério petrino e o múnus dos Bispos. Nota-se, nos textos conciliares, uma grave omissão: praticamente não se faz

\footnotetext{
${ }^{59}$ A propósito desta questão essencial para a vida eclesial, uma vez que a experiência de Jesus Cristo sem referência à historicidade da Encarnação pode nos levar ao risco de conceber o cristianismo ao modo de um "mito", ou coisa parecida, citemos aqui: N. AFANASSIEFF, L'Église du Saint-Esprit, Paris: Cerf, 1975, p. 156: "A eleição de Matias [cf. At 1,15-26] prolonga, de certo modo, a vida terrestre de Cristo. É evidente que somente um homem que, todo o tempo, acompanhou os discípulos de Cristo, a partir do batismo de João, poderia ser aceito como um dos Doze".

${ }^{60}$ A. ANTÓN, "La comunidad creyente, portadora de la revelación", in L. ALONSOSCHÖKEL et al. (org.), Comentarios a la constitución Dei Verbum sobre la divina revelación, Madrid: La Editorial Católica, 1969, 311-364, aqui 332-333.

${ }^{61}$ Quando celebra especificamente as festas dos Apóstolos, valendo-se da liturgia como instrumento de seu "magistério ordinário", a Igreja faz com que o Povo fiel se volte para as raízes apostólicas da Tradição eclesial. O que pensar, a propósito, da devoção popular a São Judas Tadeu como o "santo das causas perdidas"?
} 
menção ao problema da comunhão entre as Igrejas particulares como resultado da prática da colegialidade episcopal. Restringe-se o Concílio ao aspecto "pessoal" do ministério dos Bispos, acomodando-se a uma consideração dos "poderes": o poder do Papa, e aquele dos Bispos no Colégio Episcopal. Desta forma, o tratamento conciliar da questão da colegialidade episcopal sofre os condicionamentos de uma eclesiologia "universalista", a partir da qual se discute como os respectivos poderes do Papa e dos Bispos se exercem sobre a Igreja universal ${ }^{62}$. Ainda que o Concílio explicite, em determinadas passagens, uma eclesiologia das Igrejas locais, na questão precisa da colegialidade episcopal elas não são evocadas. Quando se lê o parágrafo 22 de LG, tem-se a impressão de que "parece facultativo, para pertencer ao Colégio, que um bispo presida a uma Igreja local, da mesma forma que para o Papa é determinante ser sucessor de Pedro à frente deste Colégio e pouco significativo para ele ser bispo da Igreja local de Roma" ${ }^{\prime 63}$. Este limite da síntese eclesiológica do Vaticano II aponta para o fato de que, em campo estritamente católico-romano, é ainda necessário o abandono de uma eclesiologia marcada pelo jurídico e a adoção de outro modelo eclesiológico caracteristicamente de comunhão, de tal modo que o termo "poder" - com toda a carga de legalismo que ele encerra em si - ceda lugar ao termo "serviço", mais consoante ao espírito da eclesiologia assumida como básica e determinante pelo Concílio ${ }^{64}$.

Certamente em conseqüência do fortalecimento da figura do Papa na tradição católico-romana, percebe-se nos textos do Vaticano II, quando se referem ao Colégio Episcopal, uma preocupação quiçá excessiva em se garantir a função do Bispo de Roma como Cabeça do Colégio ${ }^{65}$. Este cuidado acaba por impedir uma maior transparência e abertura na consideração do tema da colegialidade. Por certo, esta dificuldade aponta para o necessário redimensionamento do ministério da cátedra de Pedro no contexto da Igreja. Seria ilegítimo aspirar à renúncia ao valor jurisdicional do primado do Bispo de Roma, recuperando-se sua condição de primado de

${ }^{62}$ Cf. H. LEGRAND, "La réalisation de l'Église en un lieu”, in B. LAURET / F. REFOULÉ (org.), Initiation à la pratique de la théologie, Tome III: Dogmatique 2, Paris: Cerf, 1983, pp. 143-345, aqui p. 300.

${ }^{63}$ H. LEGRAND, "La réalisation de l'Église en un lieu", op. cit.,p. 300.

${ }^{64}$ A respeito desta questão, não deixa de ser sugestiva a seguinte formulação de BERNARDO DE CLARAVAL, De consideratione ad Eugenium III, II, 6, 11 (PL 182,748): "Qui major est vestrum, fiat sicut junior; et qui praecessor est, sicut qui ministrat. Forma apostolica haec est: dominatio interdicitur, indicitur ministratio, quae et commendatur ipsius exemplo Legislatoris, qui secutus adjungit: Ego autem in medio vestrum sum, tanquam qui ministrat (Luc. XXI, 26, 27)".

${ }^{65}$ Cf. P. TIHON, "L’Église", op. cit., p. 530. 
honra? Tal "redução" não nos poria a nós, católicos romanos, em sintonia com a Tradição eclesial? ${ }^{66}$

\section{Conclusão}

O Colégio Episcopal, por si e em si próprio, significa e manifesta o sempre atual desejo que teve Jesus de constituir a sua Igreja a partir do chamamento de doze homens, para estabelecer comunhão com eles e enviá-los em missão. Desta forma, o conteúdo básico a ser comunicado pelos Apóstolos em missão, bem como pelos seus sucessores ao longo dos séculos, é a experiência de que o Deus confessado pelos cristãos é, em si mesmo, comunhão entre as Pessoas divinas (cf. Mt 28,19). Os Bispos, sucessores dos Apóstolos, são, com efeito, sacramento destas colunas de sustentação do edifício eclesial (cf. Ap 21,14), que tem em Jesus Cristo a sua pedra angular (cf. Ef 2,20); ou melhor, são sacramento de que a vontade de Deus é que a sua Igreja seja, antes de tudo, experiência de comunhão. Portanto, o exercício colegial do ministério dos Bispos na Igreja não se reduz a uma mera "solução" organizacional. O múnus episcopal, praticado em colégio, é precipuamente testemunho de que Deus, na graça de Jesus Cristo e na virtude do Espírito Santo, faz aliança com os homens, aliança esta a se consumar nos últimos tempos. Praticada autenticamente, a colegialidade episcopal não deixará de dar frutos em prol da construção de uma sonhada Igreja da participação e da comunhão, o que corresponderia a uma eclesiologia "circular", com a concomitante correção dos inconvenientes de uma eclesiologia "piramidal".

Em eclesiologia, o "universal" e o "particular" não se excluem mutuamente. A dinâmica própria da Igreja local não significa fechamento em relação à Igreja universal: pelo contrário, é na vivência dos valores evangélicos in loco que a Igreja "católica" se manifesta. Num determinado local, os cris-

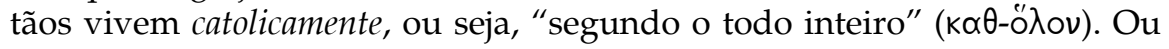
seja, é nos limites de uma Igreja diocesana, que Jesus Cristo é confessado como único mediador entre Deus e os homens, como aquele que "a si mesmo se deu em resgate por todos", em cumprimento à vontade do Deus que "deseja que todos os homens sejam salvos e cheguem ao pleno conhecimento da verdade" (cf. 1Tm 1,1-6). Outrossim, é no hoje que se vive a comunhão com a Tradição eclesial: se há uma comunhão segundo o espaço entre as Igrejas contemporâneas, há também uma comunhão segundo o tempo que vivemos com aqueles que nos antecederam na fé em Cristo

${ }^{66}$ Para uma consideração histórica deste problema, consulte-se K. SCHATZ, La primauté du pape. Son histoire des origines à nos jours, Paris: Cerf, 1992, pp. 44-51. 
Jesus. Aqui, há autêntica comunhão in Ecclesia com aqueles que nos transmitiram de modo íntegro a fé cristã ${ }^{77}$.

O Concílio Vaticano II, ao desenvolver a doutrina do episcopado, e ao interno dela, a da colegialidade episcopal, convida-nos a buscar formas de se praticar a difícil e delicada articulação entre "primado petrino" e "colegialidade episcopal". Na base desta articulação, encontra-se a própria tensão construtiva entre "unidade" e "diversidade", que, enquanto característica da comunhão eclesial, tem na Trindade Santíssima sua raiz e modelo $^{68}$.

$\mathrm{Na}$ eclesiologia católico-romana sempre se deu grande valor à dimensão pessoal das funções hierárquicas - quer do Bispo de Roma, quer dos Bispos diocesanos -, em detrimento de uma reflexão mais acurada sobre a colegialidade (ou sinodalidade) episcopal ${ }^{69}$. Tal busca não encontraria no diálogo ecumênico um locus theologicus privilegiado, na medida em que esta questão tem implicações ecumênicas as mais sérias? ${ }^{70}$

Em termos de reflexão teológica, talvez se tenha insistido, até o presente, na compreensão teórica da relação entre "primado petrino" e "colegialidade episcopal". Este procedimento tem nos levado a impasses aparentemente irremediáveis. Quiçá não seria melhor que, antes de se chegar a uma precisa formulação teórica desta relação, às Conferências Episcopais fosse dada a liberdade de atuarem mais autonomamente ${ }^{71}$, o que, a um só tempo, suporia e alimentaria uma relação de confiança e de

${ }^{67}$ Ver, a propósito, G. BRUNI, "Ecclesiologia eucaristica percorso di unità?", Studi Ecumenici 18 (2000) 131-146, aqui pp. 133s.

${ }^{68}$ Consultem-se, a propósito, P. EVDOKIMOV, L’Orthodoxie, Paris: Desclée De Brouwer, 1979, p. 135; Y. CONGAR, «La Tri-unité de Dieu et de l'Église», in IDEM, Essais œcuméniques, op. cit., pp. 297-312, aqui pp. 310-312.

${ }^{69}$ Cf. B. SESBOÜÉ, "Les Conférences épiscopales en question", op. cit., p. 236.

${ }^{70}$ Recordemos que algumas conclusões do Grupo de Dombes, quando se discutem questões relacionadas à autoridade exercida na Igreja de Cristo, assinalam a necessária integração dos aspectos comunitário, colegial e pessoal dos ofícios hierárquicos: cf. GRUPPO DI DOMBES, "Il ministero di comunione nella chiesa universale", in G. CERETI / S. J. VOICU (org.), Enchiridion oecumenicum. Documenti del dialogo teologico interconfessionale, Bologna: Dehoniane, 1988, v. 2, pp. 427-494, aqui pp. 480-485; GROUPE DES DOMBES, "Un seul Maître". L'autorité doctrinale dans l'Église, Paris: Bayard, 2005, pp. 159-161.

${ }^{71}$ Advirta-se que "autonomamente" não significa "independentemente". A "autonomia" diz respeito a decisões ou procedimentos responsáveis, de uma pessoa ou de um sujeito coletivo, com base no princípio da subsidiariedade. A "independência", por seu turno, traduz o puro e simples desligamento, por parte de uma pessoa ou de um sujeito coletivo, de uma determinada instituição. Em termos de eclesiologia, a "independência" de um grupo separado da Igreja configura-se como cisma. 
ajuda mútua entre a Sé romana e as Conferências de Bispos? ${ }^{72}$ Como atesta a história da Igreja, não deveria a prática preceder a teoria, uma vez que a Igreja não é uma realidade estática, mas um corpo vivificado pelo Espírito do Ressuscitado?

Paulo César Barros SJ é mestre (1997) e doutor (2002) em teologia dogmática pela Pontifícia Universidade Gregoriana com a tese "Commendatur vobis in isto pane quomodo unitatem amare debeatis": a eclesiologia eucarística nos Sermões ad populum de Agostinho de Hipona e o movimento ecumênico, Roma: Gregoriana, 2002 (Série Tesi Gregoriana, 83). Atualmente, é professor de eclesiologia no Centro de Estudos Superiores da Companhia de Jesus, em Belo Horizonte.

Endereço: Av. Dr. Cristiano Guimarães, 2127 31720-300 Belo Horizonte - MG

e-mail: pcbarrossj@hotmail.com

${ }^{72}$ No amplo contexto da comunhão eclesial, as Conferências Episcopais são um "elemento na cadeia de sinodalidades que pertencem ao mistério da Igreja" (B. SESBOÜÉ, "Les Conférences épiscopales en question", op. cit., p. 236). 